\title{
THE FINANCIAL PERFORMANCE OF AGRICULTURAL HOLDINGS IN ROMANIA - REGIONAL ANALYSIS
}

\author{
Camelia Burja ${ }^{1}$ \\ Vasile Burja
}

\begin{abstract}
The paper presents an evaluation of the financial performance of agricultural holdings in Romania after the EU integration. To capture the most significant aspects of efficiency regarding agricultural activities, the paper presents a spatial perspective of performance on regions of development based on the evolution of some significant financial indicators. The financial ratios used in the paper present the evolution of performance for agricultural holdings by region, and by using the Data Envelopment Analysis method, a picture of their relative financial performance was obtained. The analysis revealed the top performing farms, the relative positioning of the others and their trends.
\end{abstract}

Key words: financial performance, agricultural holdings, financial ratios, Data Envelopment Analysis

Jel Codes: O13, Q12, Q14

\section{Introduction}

Since its launched (1962), the Common Agricultural Policy set goals and ways of development for the agriculture of EU member countries. Successive reforms of the CAP focused on creating more market-oriented agricultural sectors, support to producers and increase their incomes, integration of environmental requirements into development strategies and stimulate rural development. However European agriculture still face external challenges in achieving sustainable development. The new CAP 2014-2020 intends to continue the reforms begun, and especially encourage producers to address these challenges. The objectives of the new CAP reform intend that during the coming years, the agriculture of the EU member states considerably improves viability and competitiveness becoming more sustainable and efficient (EC, 2013).

In this context, farms in Romania too, must face economic, social, environmental and technological challenges of contemporary society and operate in accordance with the principles of the sustainable development concept. Given the priorities of the EU rural development policy reaffirmed in the new CAP reform, farms will have to exercise a role more and more important in the rural economy and fulfil multiple functions. They are the main actors that can contribute to a more sustainable sector in agriculture, characterized by a high level of performance and economic competitiveness. Agriculture ensures the preservation and enhancing of ecosystems, promotes climate resilient economy and helps promote social inclusion in rural areas (EC, 2013).

Currently, the Romanian agriculture is a subsistence agriculture characterized by reduced performance resulting from numerous problems it faced: excessive fragmentation of land which causes poor land management, insufficient and aging labour force, low productivity, high prices

\footnotetext{
1 “1 Decembrie 1918” University, Faculty of Science, Alba Iulia, e-mail:cameliaburja@yahoo.com
} 
of agricultural inputs, the absence of integrated value chains of agricultural products, the lack of a functional system of agricultural credit, and negative environmental impact (Burja, 2011). Romanian agriculture still has a significant share in the national gross domestic product of $5.3 \%$ (2012) and 29\% of total employment in the country. Romania holds $7.8 \%$ of the utilized agricultural area of EU-27 and $15.8 \%$ of the total labour force input, which suggests that it has a high agricultural potential within the EU (EC, Eurostat). This potential is not, however, fully exploited.

Labour productivity in Romanian agriculture (Total Output /Labour input) is 4.9 times lower than in the EU and land productivity (Total output/Total utilized Agricultural Area) is 1.5 times lower than the level of the EU. This situation shows that the factors of production used in agriculture are used with low efficiency. There are also differences in terms of territorial performance (Burja, 2011).

To achieve a more sustainable management of agricultural sector's companies, there is a need of a better foundation of decision-making processes, particularly those addressing the issues of the efficient use of resources. Information on the performance recorded by an economic system reflects not only the management of resources involved in the activity but also the achievement of a state of balanced and efficient functioning, which gives it competitiveness and a certain position towards the competitors. The current International Financial Reporting Standards (IFRS) meet the needs of monitoring and evaluation the companies activity and facilitate economic and financial performance analysis.

The purpose of this paper is to evaluate the financial performance of agricultural holdings. The analysis is based on the main key indicators of companies annual financial reports showing the financial position and performance. To achieve its purpose, this paper utilises a model of performance evaluation using the flow of financial information and Data Envelopment Analysis (DEA) techniques. The adopted methodology allows a relative assessment of the financial performance of holdings by development regions.

This paper contributes to the development of possibilities of microeconomic efficiency analysis and performance evaluation practices of activity in agricultural holdings and it can be a support in decision making processes for the development of the agricultural sector.

\section{Literature Review}

Performance of companies is a topic frequently discussed in the literature duet o the strong correlation between the deployment on efficient bases of activity in any field of activity and economic survival in the competitive environment. Indicators of performance evaluation are diverse and they reflect the degree to which organizations maximize their results against available resources. The success of a business depends on the efficient operation of each component, and from this point of view, in businesses, performance monitoring should cover the investment cycle and operating cycle or target various fields such as production, investment, commercial activities, financial activities, human resources, management functions.

The current system of annual financial reports of companies facilitates monitoring and performance evaluation with the help of financial indicators. They synthetically express the whole activity operation, provide control over the use of resources and obtained efficiency and allow the identification of adjustments required to increase results and company value. Financial indicators provide a real basis for performance analysis and evaluation of the financial health of the company (Knight and Bentoneche, 2001). The information provided by indicators and the financial analysis techniques are used by the traditional system of performance evaluation. A number of studies used financial rates to make the performance analysis and determine the financial position for companies of various fields of activity (Gallizo and Salvador, 2003; Chen and Shimerda, 1981; Singh and Schmidgall, 2002). 
For a better understanding of company performance and competitiveness, it is considered that traditional accounting-based performance measures must be completed by value-based performance measures. This approach to analyze the performance is based on the theory of Modigliani Miller (1958) on the determinants of value and led to the development of some alternative evaluation indicators of financial performance such as: Free Cash Flow, Economic Value Added, Market Value Added.

Other analytical models utilize fuzzy methods to rank traditional or value-based financial performance measures and have been used for ranking organizations within the sector they belong to (Yalcin et. al, 2012).

The usefulness of traditional accounting-based performance measures is demonstrated by their widespread use in the performance analysis models. When making comparisons between several companies, using a large number of performance financial ratios or their aggregation in a synthetic indicator becomes a complicated problem.

A performance analysis methodology often used in economic systems and which facilitates the establishment of the relative efficiency of some decision making units according to certain predetermined criteria, is the Data Envelopment Analysis. DEA methodology has been applied in various fields. In agriculture the method was used to determine the competitiveness of the agricultural sectors of countries (Coelli and Rao, 2003; Lissitsa et al., 2007; Rasmunssen, 2010), assessment of agriculture sustainability (Ehrmann and Kleinhanss, 2008), identifying the efficiency determinants of agricultural production systems (Latruffe et al., 2004), comparisons of the efficiency of organic and traditional culture system (Beltran-Esteve and Reig -Martinez, 2014) etc.

For Romania, studies using DEA in relation to resources and performance management in the agriculture sector are relatively few. They determine the agricultural performance differences between regions (Burja, 2011), assess the efficiency of agricultural production (Aldea and Vidican, 2007) or present the farming efficiency of EU member states (Balezentis, 2011).

\section{Data and methodology}

The dataset used in this study refer to agricultural holdings in Romania which, due to their size can be considered of commercial type. Information was taken from the Farm Accountancy Data Network (FADN), which contains information about the activities of agricultural holdings in the European Union member countries.

Information from FADN allows studying both economic performance and financial performance. This study carried out an assessment of the financial performance and used representative indicators for its specific areas of analysis. The study completes the previous research results that make particular reference to the performance of agricultural production factors (Burja, 2011; Aldea and Vidican, 2007). The indicators used in the analysis are calculated as financial rates of profitability, liquidity, solvency and efficiency of business both in the agricultural holdings in Romania and the EU as a whole for the period 2007-2011. For a more complex characterization of the phenomenon studied, information about farms in Romania are divided into 8 regions (NUTs II level), namely: North-East, South-East, South-Muntenia, South-West Oltenia, West, North-West, Centre and Bucharest-Ilfov. As the number of agricultural holdings in Bucharest-Ilfov region is very small (0.4\% of the total) and the area is highly non-agriculture in character, it was excluded from the analysis.

To achieve the main objective of the research, namely assessing the performance of agricultural holdings in Romania, we used DEA methodology. This methodology is based on classic linear programming model that contains $k$ decision units with $n$ inputs and $m$ outputs (Charnes et al, 1978): 


$$
\max \sum_{j=1}^{m} v_{j} y_{k j} \quad \text { s.t. } \sum_{i=1}^{n} u_{i} x_{k i}=1 \quad \sum_{j=1}^{m} v_{j} y_{k j}-\sum_{i=1}^{n} u_{i} x_{k i} \leq 0
$$

in which: $u_{i}$ represent the weights of inputs $(x)$;

$v_{j}$ are the weights of outputs $(y)$.

In this paper, DEA method was selected because of the advantages it has as it best meets the needs of achieving research objectives. With it one can determine the relative efficiency of Romania agricultural holdings by taking into account the simultaneous action of several variables and a comparison of the financial performance of the systems analyzed can be also made.

The variables used in the model as inputs or output variables to measure financial performance are: Return on Assets, Current Ratio, Debts to Equity Ratio, Assets Turnover Ratio and Farm Net Value Added. Appreciation of performance using financial ratio in DEA models is an addition to the simple ratio analysis usually employed (Balezentis, 2011). The performance indicator built in DEA model in this study expresses synthetically the determinants of performance, namely: profitability, liquidity, solvency and activity efficiency.

The "Return on Assets ratio" indicator is a measure of profitability and shows how much profit a company generates by using its current and non-current productive assets. It is calculated by dividing the net income to the total assets of the company. A high ratio indicates increased performance.

Liquidity ratios expresses the capacity of a firm to pay its short-term obligations and more suggestive of them is "Current ratio", calculated as total current assets divided by total liabilities. This rate is the relative expression of a working capital indicating the capital that must secure the financing a company's daily activities. The reference level of Current ratio is 2: 1, and one of its lower values may be a sign of concern (Posthumus et al., 2013). A higher level indicates the existence of financial equilibrium and adequate funding of activities that are prerequisites for the efficient conduct of business.

"Debt to Equity ratio" indicates a company's solvency and its financial stability. A level of rate greater than 1 indicates that the company can not pay its debts, has not a adequate funding policy and is subject to risks in case of financial conditions deterioration. The rate demonstrates the financial leverage effect and its level has a strong impact on the performance of a company.

The "Assets Turnover ratio" indicator expresses the efficiency with which a firm manages its available resources to generate sales. For agricultural holdings this can be calculated by dividing the total output indicator to total assets. The indicator also shows the number of times the assets are turned into revenues during the year, a higher number shows a higher efficiency.

"Farm Net Value Added" is a newly created value and ensures remuneration of all production factors employed. The level of indicator directly influences the efficiency of agricultural holdings.

Measuring financial performance scores is done using DEA method applied in the form of the output-oriented constant returns to scale (CRS), also called CCR after its creators Charnes, Cooper and Rhodes (1978). To solve the model we used DEA software.

\section{Results and Discussions}


In 2011, Romania had the highest number of agricultural holdings in the EU, namely 1042220 commercial farms. Compared to 2007, agricultural holdings increased their economic size by $40 \%$ (9.2 ESU), but still have a size of approx. 6.3 times lower than the average indicator in EU27 (FADN, 2014).

The situation of key financial performance indicators for Romania and EU is presented in Table 1.

Table 1

Financial performance indicators of agricultural holdings

in Romania and EU, 2007-2011

\begin{tabular}{|l|c|c|}
\hline \multirow{2}{*}{ Indicators } & \multicolumn{2}{|c|}{ Mean values } \\
\cline { 2 - 3 } & Romania & EU 27 \\
\hline Current ratio & 75.1 & 5.6 \\
\hline Debt to Equity ratio, \% & 3.0 & 17.4 \\
\hline Assets Turnover ratio & 0.36 & 0.21 \\
\hline Return on Assets ratio, \% & 12.7 & 5.9 \\
\hline Farm Net Value Added, euro/ha & 595 & 828 \\
\hline Gross Farm Income, euro/ha & 716 & 1086 \\
\hline Total output, euro/ha & 6918 & 33990 \\
\hline
\end{tabular}

Source: own calculation based on FADN database

The data in Table 1 reveal significant differences between the performance of agricultural holdings in Romania and those in the EU. Farms in Romania have a very high liquidity of the assets they manage, 75.1, exceeding by more than 13.4 times the size of the same indicator in the EU. The particularly high value of the Current Ratio is a negative aspect because it shows that holdings have significant capitals immobilized in inventories and receivables, and in the period under review, they have not adopted an active policy investment. There are also large differences in the liquidity of companies in the territory.

Debt to Equity ratio is on average 3\%, which shows that farms have low debt and high solvency. This usually indicates the existence of a good financial security of agricultural companies and that they especially use equity for development. The fact that they have not turned to long-term bank loans can be explained by the inadequate national policy lending to the agricultural sector, by the excessive prudence exercised by the banking sector lending to agriculture and the inadequate development strategies of agricultural holdings. In the period 2007-2011 the total output in the analyzed farms increased on average by $22.6 \%$.

This analyzed sector comprising holdings of commercial type apparently shows a better performance compared to the European average in the use of their patrimony. Agricultural holdings in Romania have Return on Assets ratio over two times higher than those in the EU. Indicators in absolute value present however a different financial situation. Thus, the Farm Net Value Added / ha in Romanian holdings is more than $28 \%$ lower than the European average, Gross Farm Income / ha is lower with more than 34\%, while the Total output / ha is reduced by almost $80 \%$.

The conclusions obtained are both favourable and unfavourable aspects related to financial performance. To obtain an accurate assessment of performance but given the many aspects that influence it, there is an need to build a model of analysis that includes all elements of impact and provides synthetic scores of companies performance. An analysis of farms on development regions in Romania shows disparities in financial performance between them. DEA method was applied to the group of commercial agricultural holdings selected, in the version CRS output oriented model. The output component is the variable Return on Assets (ROA) and the input components are Current Ratio (CR), Debt to Equity ratio (DER), Assets Turnover ratio 
(ATR) and Farm Net Value Added / ha (FNVA). Estimated efficiency of DEA results is presented in Table 2.

Table 2

DEA results: efficiency scores of Romania agricultural holdings, 2007-2011

\begin{tabular}{|l|l|l|l|l|l|}
\hline Holdings & \multicolumn{5}{|l|}{$\begin{array}{l}\text { Efficiency scores } \\
\text { output variable: ROA } \\
\text { input variables: CR, DER, ATR, FNVA }\end{array}$} \\
\cline { 2 - 7 } & $\mathbf{2 0 0 7}$ & $\mathbf{2 0 0 8}$ & $\mathbf{2 0 0 9}$ & $\mathbf{2 0 1 0}$ & $\mathbf{2 0 1 1}$ \\
\hline North-East & 1 & 0.959 & 1 & 1 & 1 \\
\hline South-East & 0.582 & 1 & 1 & 1 & 1 \\
\hline South-Muntenia & 0.788 & 1 & 0.781 & 0.693 & 0.813 \\
\hline South-West-Oltenia & 1 & 1 & 1 & 1 & 1 \\
\hline West & 0.599 & 1 & 1 & 1 & 1 \\
\hline North-West & 1 & 1 & 1 & 0.903 & 0.916 \\
\hline Center & 0.395 & 0.754 & 0.710 & 1 & 0.951 \\
\hline mean - Romania & 0.766 & 0.959 & 0.927 & 0.942 & 0.954 \\
\hline
\end{tabular}

Source: computations were performed using Deap 2.1

According to the obtained results only holdings in one region (South-West Oltenia) have a relative efficiency throughout the period 2007-2011. The average overall efficiency score for commercial farms was $76.6 \%$ in 2007 , registering an increase of the score with almost $19 \%$ in 2011.

In the period under review, however, holdings considered efficient decreased in number. Thus, in 2011 the efficiency frontier displays 71,410 fewer farms than in 2007. They represent over $57 \%$ of the total commercial agricultural sector in the year 2011. The efficient agricultural holdings structure on regions was also changed; currently, there are 4 regions with relative agricultural efficiency, in lieu of 3 areas in 2007 (Figure 1). Farms with scores of maximum efficiency and therefore with performance are found in North-East regions, SouthEast, South-West Oltenia and West.

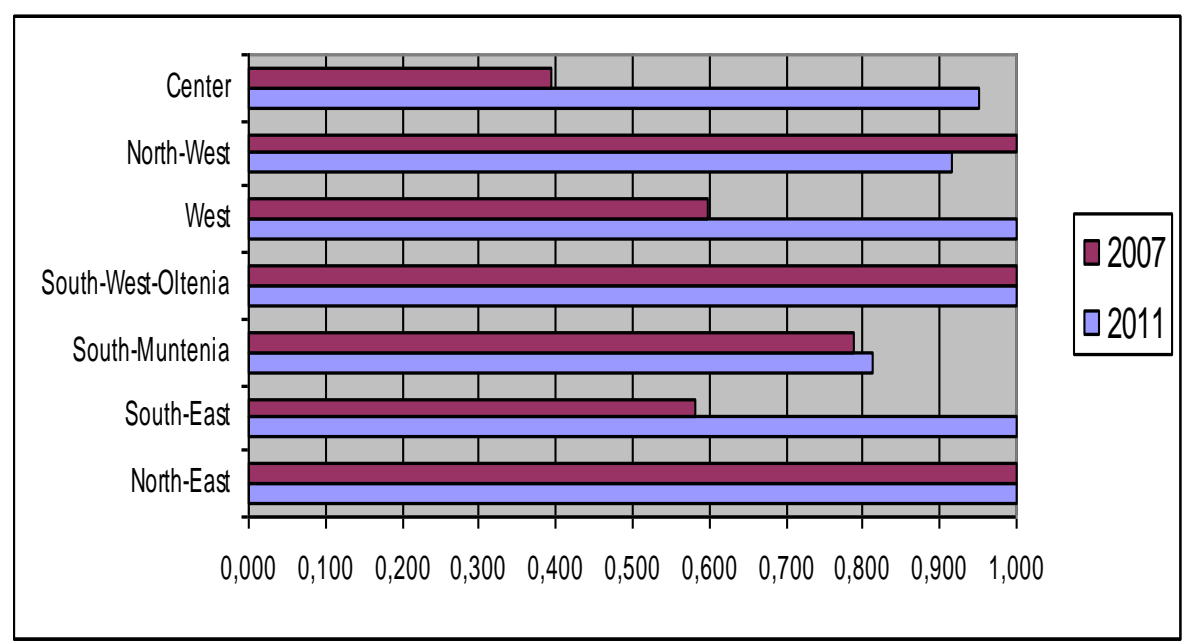

Figure 1. Relative efficiency scores of agricultural holdings in Romania by development regions, 2007 and 2011

In the year 2011, it appears that there is still a large number of farms (442500 holdings, ie $43 \%$ of the total) who have not yet reached the expected level of performance and they are in the 
three regions with efficiency scores below unit (South-Muntenia, North-West and Centre). They need to improve their efficiency, which requires both improving economic strategies and financial ones. These holdings must adopt better management of resources, to increase their land, labour and capital productivity, and become more competitive to as rationally exploit their potential (Burja, 2011).

According to obtained results on farms identified as having scores of lower efficiency, there is a need to increase financial performance measures. They should stimulate the appropriate correlation of needs with funding sources at both the investment level and the current activity level. It is also necessary to improve overall business decisions on funding, proper management of assets and capital which must accelerate the speed of rotation in order to contribute to a greater extent to increase turnover and profit. The combined use of different sources of funding to ensure implementation of investment strategies for increasing the productive potential provides at the same time a high solvency and adequate liquidity. The financial risk mitigation sends positive signals to investors, banks, institutions, commercial partners and other stakeholders.

\section{Conclusions}

The research sought to evaluate the performance of agricultural holdings in Romania grouped by the territorial criteria in the period 2007-2011. By addressing financial performance we aimed to highlight the impact of financial management measures on company efficiency in agriculture. Financial decisions provide the directioning of funding sources to a particular material composition of patrimony, and the ways to use production factors. Given the performance evaluation financially, factors with significant impact on the phenomenon, described by financial rates, were selected for analysis.

The rates of liquidity, solvency, efficiency and profitability, in addition with the value added performance indicator, were used as variables to develop a DEA model. The efficiency scores obtained by solving the linear programming DEA model reflect the financial performance level of farms in the territory.

The results obtained from the variables considered in the model show that not all agricultural holdings in Romania have achieved maximum levels of efficiency. In 2011, in the commercial agricultural sector there were still $43 \%$ of farms with lower efficiency in three areas of the country. Even though the vast majority of these have made progress compared to 2007, there has not yet been reached the potential maximum efficiency. Through better management of existing resources and capital at their disposal, they can increase their own performance by 5 $19 \%$. Increasing resource efficiency is the way of financial performance growth and competitiveness of agricultural holdings.

\section{References}

1. Aldea A., Vidican G.,2007, Efficiency in agricultural production: Regional evidence from Romania, Economic Computation and Economic Cybernetics Studies and Research, 41(3-4), pp. 245-255.

2. Balezentis T., A., 2011, Multi-Criteria Assessment of Relative Farming Efficiency in the European Union Member States, Zemes Ukio Mokslai, 18(3), pp. 125-135.

3. Beltran-Esteve M., Rei-Martinez E., 2014, Comparing Conventional and Organic Citrus Grower Efficiency in Spain, Agricultural Systems, Vol. 129, pp. 115-123;

4. Burja V., 2011. Regional Disparities of Agricultural Performance in Romania, Annales Universitatis Apulensis Series Oeconomica, 13(1), .

5. Charnes A., Cooper W., Rhodes, 1978, Measuring the Efficiency of Decision-Making Units, European Journal of Operational Research, 2, 429-444 (1978). 
6. Chen K. H., Shimerda T. A., 1981, An Empirical Analysis of Useful Financial Ratios, Financial Management, 10 (1).

7. Coelli, T.J., Rao D.S.P., 2003, Total Factor Productivity Growth in Agriculture: A Malmquist Index Analysis of 93 Countries, 1980-2000, Agricultural Economics.

8. EC European Commission, 2013, Overview of CAP Reform 2014-2020, Available at: http://ec.europa.eu/agriculture/policy-perspectives/policy-briefs/05_en.pdf, Accessed 17 July 2014.

9. EC European Commission, Eurostat database.

10. Ehrmann M., Kleinhanss W., 2008, Review of Concepts for the Evaluation of Sustainable Agriculture in Germany and Comparison of Measurement Schemes for Farm Sustainability, Arbeitsberichte aus der vTI-Agrarökonomie, no.14/2008, Johann Heinrich von Thünen.

11. Gallizo J.L., Salvador M., 2003, Understanding the Behaviour of Financial Ratios. The Adjustment Process, Journal of Economics and Business, 55(3), p. 267-283.

12. Knight R., Bentoneche M., 2001, Financial Performance, Reed Educational and Professional Publishing Ltd, Oxford.

13. Latruffe L., Balcombe K., Davidova S., Zawalinska K., 2004, Determinants of Technical Efficiency of Crop and Livestock Farms in Poland, Applied Economics, Taylor and Francis Journals, vol. 36 (12), pp. 1255-1263.

14. Lissitsa, A., Rungsuriyawiboom S., Parkhomenko S., 2007, How Far Are the Transition Countries from the Economic Standards of the European Union? Measuring Effciency and Growth in Agriculture, Eastern European Economics, 45 (3), 51-75.

15. Modigliani F., Miller M., 1958, The Cost of Capital, Corporate Finance and the Theory of Investment, American Economic Review, 48 (4).

16. Singh A. J., Schmidgall R. S., 2002, Analysis of Financial Ratios Commonly Used by US Lodging Financial Executives, Retail and Leisure Property, 2 (3).

17. Rasmunssen S, 2010, Scale Efficiency in Danish Agriculture: An Input DistanceFunction Approach, European Review of Agricultural Economics, 37 (3), 335-367.

18. Yalcin N., Bayrakdaroglu A., Kahraman C., 2012, Application of Fuzzy Multi-Criteria Decision Making Methods for Financial Performance Evaluation of Turkish Manufacturing Industries, Expert Systems with Applications, 39. 